\title{
PROJECTIONS FOR THE LATVIAN DAIRY AND BEEF SECTOR
}

\author{
Aleksejs Nipers, Irina Pilvere, Sandija Zeverte-Rivza \\ Latvia University of Agriculture \\ aleksejs.nipers@1lu.lv; irina.pilvere@1lu.lv; sandija.rivza@1lu.lv
}

\begin{abstract}
Milk production is the second most important agricultural sector in Latvia with $17.7 \%$ in the distribution of agricultural final products in 2015. However, the proportion of milk production decreased by 5.3 percentage points in comparison with 2014, reaching the lowest proportion recorded. The agriculture of Latvia depends on the Common Agricultural Policy (CAP) that continuously changes and is reformed. The European Union (EU) decision makers have traditionally used the results of a wide range of quantitative tools in framing their choices among alternative policy instruments. To do it, it is necessary to make long-term projections for the sector. Modelling is a way of solving problems that occur in the real world. There are two important motivations for agricultural model development; 1) scientific understanding; 2) decision making or policy support. In 2016, the Latvia University of Agriculture developed the Latvian Agricultural Sector Analysis Model to simulate the development of agriculture and its key sectors for the period until 2050. The present paper reflects part of the research results - a simulation of dairy farming and a projection made for it. The following factors were taken into account when simulating the dairy sector of Latvia: commercial sales of milk, consumption of milk for food, consumption of milk for feed, milk prices, milk yields, the number of dairy cows, costs (total, as well as feed, labour and investment costs and depreciation expense), and the produced projection is useful for making policies and applying special support instruments.
\end{abstract}

Keywords: dairy farming, projections, modelling.

\section{Introduction}

Milk production is the second most important agricultural sector in Latvia with $17.7 \%$ in the distribution of agricultural final products in 2015. However, the proportion of milk production decreased by 5.3 percentage points in comparison with 2014, reaching the lowest proportion recorded. In the period 2007-2014, milk production accounted for on average $21.4 \%$ of the total value of agricultural commodities in Latvia [1]. That was under the conditions when, on the one hand, the global demand for dairy products rose, while, on the other hand, there was a complicated situation in the European market related to abolishment of milk quotas and Russia's imposed embargo. The dairy sector developed in Latvia, and it provided jobs and stabilised the economies of rural territories [2]. The current low prices for dairy commodities and milk are mainly the result of a surge in the world and EU supply at a time when China has started to reduce its purchases and Russia has introduced an import ban. However, the import demand from other regions of the world has risen significantly and is expected to grow steadily over the outlook period, driven by population growth and a change in diets in favour of dairy products. In addition, Chinese imports should resume growth [3]. Since 2004, the agriculture of Latvia has depended on the Common Agricultural Policy (CAP) and changes in it. For this reason, it is important to analyse the agricultural industries in order to forecast their development in the future and make prudent decisions aimed at fostering their development. It is usually done through producing accurate development scenarios. The EU decision makers have traditionally used the results of a wide range of quantitative tools in framing their choices among alternative policy instruments [4]. The agricultural modelling world has generated several models aiming at the analysis of the response of the sector to certain changes in exogenous mainly policy variables [5]. Modelling is a way of solving problems that occur in the real world. It is applied when prototyping or experimenting with the real system is expensive or impossible. Modelling allows you to optimize systems prior to implementation [6]. It is clear that agricultural system models have become important tools to provide predictive and assessment capability to a growing array of decision-makers in the private and public sectors, including farmers, researchers, agribusiness, and policy-makers [7]. There are two important motivations for agricultural model development: scientific understanding and decision/policy support [8].

Therefore, the overall objective of the research is to develop a dynamic simulation model for dairy farming. To achieve that, the following specific research tasks are defined: 1) to design a model for projecting dairy farming indicators that is appropriate for Latvia; 2) to produce an outlook of key indicators of the dairy sector for the period until 2050. 


\section{Materials and methods}

To generate projections for agricultural sector developments in Latvia until 2050, the Latvia University of Agriculture developed the Latvian Agricultural Sector Analysis Model (LASAM) in 2016. LASAM is an econometric, recursive, dynamic, multi-period scenario model, which can also simulate GHG emissions. Most of the estimations within the model are done by performing linear regression, the regression models are evaluated by their statistical significance and the coefficient of determination. Sensitivity analysis is used to calculate possible deviations of the results from the projected base scenario,

It covers all agricultural sectors. Using the LASAM parameters, exogenous data and lagged endogenous data, it is possible to generate projections for the model's endogenous variables over a set of alternative policy scenarios and over a given projection period. However, due to the research limitations, the present research deals with only a part of the LASAM model, presenting a simulation of dairy farming and a projection produced for it for the period until 2050 [9]. The key information sources used by the present research were as follows: the Central statistical Bureau (CSB) of Latvia and the Agricultural Data Centre (ADC), FADN data on dairy farms and the Rural Support Service (RSS) database on support payments. Verification of LASAM was done using several approaches. First, the historical data were compared with the back-looking modelling results. Second, examination of model output results reasonability was done to understand weather projections are within logical limits. Third, experts in agriculture from the main Latvian stakeholder organisations were involved to verify the main logical constructions of the model and the results. In addition, verification of LASAM was done by performing a one-step analysis, in the meantime model validation was performed by comparing the results of LASAM with the national level simulation model for agricultural sectoral developments and GHG emissions elaborated by a group of researchers in 2015 [22].

\section{Results and discussion}

\section{Development of the model for dairy farming}

Total milk output has to be separated from commercial milk production to project the development of milk production in Latvia. Intensive dairy farming represented by large dairy farms shaped the development of the dairy sector until 2014 and, as expected, the situation is going to be the same in the future, too. This trend is determined by farm structural changes that took place in the dairy sector in recent years, and it indicates the concentration of the dairy sector - small dairy farms leave the market, whereas large and competitive ones continue expanding and increasing their numbers of cows.

In view of the mentioned factors, as well as labour cost increases and greater opportunities for large dairy farms to attract investments, one can expect that particularly this group of farms is going to increase in number, whereas the number of small dairy farms will continue decreasing. Projections produced by the LASAM model divide total milk output into three components: 1) milk sold for processing; 2) consumption of milk for food; 3) consumption of milk for feed.

The "milk sold for processing" component consists of sub-components that comprise the data basis for calculating the quantity of milk sold for processing: 1) a milk price projection; 2) a milk yield projection; 3) a projection of costs: purchased feed cost, labour cost, depreciation expense and total cost [9].

Milk sold for processing. Most of the milk produced is intended for commercial sale to milk processing enterprises. In the period 1995-2015 in Latvia, milk sales to processing enterprises more than doubled - from 321 thou.t to 808 thou.t. It has to be noted that earlier - in 1990 - the quantity of milk purchased by processing enterprises totalled 1611 thou.t, which was two times more than in 2015 [10]. Besides, changes took place not only with regard to milk producers. The increase in the quantity of milk sold for processing in the period 2005-2015 was, to a great extent, due to increase in exports of milk and dairy products. However, significant structural changes regarding milk producers and their markets for sales took place despite the relatively small change in the total output of milk.

A number of factors, which have changed during the course of time, have influenced the quantity of milk produced for selling to milk processors. Financially, they are the price, support payments, 
costs of goods, services, labour, land and other inputs related to milk production. Besides, opportunities for dairy exports were limited (due to quotas, tariffs, different price and support levels) before the accession to the EU. After joining the EU, the opportunities for dairy exports to the EU considerably increased. Even though milk production quotas existed in the EU until 2015, the quantity of milk produced for commercial sale increased in Latvia, which was partly due to the structural change in agriculture - a lot of micro-farms that produced milk for own consumption stopped operating [11]. For these reasons, the present research primarily focuses on financial factors and the period after Latvia's accession to the EU when the "rules of the game" in the dairy sector became different from those existing before. Given the fact that, on the one hand, a number of factors can potentially influence milk production for commercial sale, while, on the other hand, the time series is quite short, the aggregated index approach was applied to the identification of the factors. By calculating the revenue and expense index for milk production [12] and econometrically assessing the index influence on the quantity of milk sold to milk processors [10], it is possible to determine the influence of the index quantitatively. Assuming that the influence of the ratio of revenue to expense is constant in a long-term, one can project the output of milk for sale based on a forecast of the value of the ratio of revenue to expense.

Changes in the quantity of milk sold for processing (milk_k_tt), compared with the previous year, are calculated as a function of the milk price (p_t_milk) [13] and amount of financial support $\left(A \_t \_m i l k\right)[14]$ divided by the milk production cost $\left(I Z \_t \_m i l k\right)[12]$ :

$$
m i l k \_k \_t t=f\left(\left(p \_t \_m i l k+A \_t \_m i l k\right) / I Z \_t \_m i l k\right) \text {. }
$$

Consumption of milk for food. Milk production for own consumption and commercial sale is determined by various factors. Some part of milk produced for own consumption is used for feed (which is included in the total output of milk), yet the proportion is higher for the milk used for food than for feed. Compared with the milk production for processing, it is determined by other factors. For this reason, own consumption of milk for food and for feed is simulated based on the past trends. Since the number of small farms declines, one can expect that the own consumption of milk (milk_p_tt) [12] will continue decreasing as well:

$$
\text { milk_p_tt }=f\left(\text { milk } \_p \_t t(-1), \log (\text { trend })\right) \text {. }
$$

Consumption of milk for feed. Just like the consumption of milk for food, the consumption of milk for feed purposes and its proportion in the total output of milk have historically decreased as well. In 2000, it was $20 \%$ of the total output, while in 2015 it was slightly more than $7 \%$ [15-17]. Even though the past trend indicates that such a decrease could continue over next years, the decrease, however, should be limited and should stabilise at a $5.5 \%$ level by 2050 . It has to be noted that in this case it is, to a great extent, due to the structural change of dairy farms rather than the sale of milk that was earlier used for feed [11].

There is an explicit decreasing trend for both cases (own consumption of milk for food and for feed), which is mainly due to the structural change of dairy farms and the increasing efficiency of commercial milk production. Even though the milk prices decreased in 2009 (and own consumption of milk increased), these were short-term fluctuations within a long-term trend [13].

Changes in the consumption of milk for feed (milk_l_tt) are calculated as a function of the ratio of

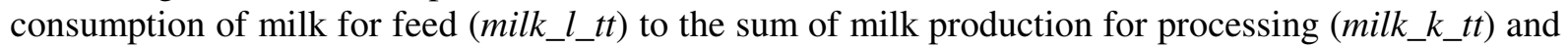
own consumption for food (milk_p_tt) and of decrease rate (dec_rate):

$$
m i l k \_l \_t t=f\left(\left(m i l k \_l \_t t\left(m i l k \_k \_t t+m i l k \_p \_t t\right)\right), d e c \_r a t e\right) \text {. }
$$

Based on the following three indicators: milk production for processing (milk_k_tt), consumption of milk for food (milk_p_tt) and consumption of milk for feed (milk_l_tt), the total output of milk is calculated (milk_tt) as follows:

$$
m i l k \_t t=m i l k \_k \_t t+m i l k \_p \_t t+m i l k \_l \_t t .
$$

Milk price projections. The dairy sector is one of the agricultural sectors that experienced rapid price changes and "crisis" periods when the milk price decreased below its production cost; it particularly related to small dairy farms, the milk price for which was approximately $10 \%$ lower than for the other dairy farms. In Latvia, the price on milk strongly correlates with that in the global market 
and in the EU; therefore, the global price changes influence the domestic milk price and cause rapid milk price fluctuations. The prices on milk in Lithuania and Estonia are practically identical to the price in Latvia; accordingly, the competitiveness of the dairy sector in the Baltic States is determined by the optimisation of milk production costs and the quantity of milk processed. An analysis of milk price changes in Latvia in the period 2005-2015 shows that there were two periods when the price on milk sharply decreased: the period 2008-2009 and the beginning of 2015. The price on milk in Latvia is, on average, $20 \%$ lower than in the EU, but in the mentioned periods it was even $30 \%$ lower than in the EU. In 2015, an increase in the difference in the milk price between the EU and Latvia was determined by Russia's embargo that made the most direct influence on the neighbouring countries of Russia, which was their market for milk exports [13].

After analysing monthly milk price changes in Latvia in the period 2006-2016, one can find that no explicit seasonal changes in the milk price were observed, and the milk purchase price was considerably affected by other political and economic factors [17].

An exogenous milk price forecast ( $\left.p \_t \_m i l k \_p r \_d g a g r i\right)$ produced by the European Commission Directorate-General for Agriculture and Rural Development (DG AGRI) [3] for the period until 2025 was employed by the model to make a milk price projection ( $p \_t$ _milk) for Latvia. A projection for the coming years - until 2050 - was extrapolated from the trend forecasted by the DG AGRI. To calculate the milk price for Latvia based on the DG AGRI forecasted prices for the EU, it was assumed that the average milk price in Latvia accounted for $85 \%$ of the EU-15 milk price (p_milk_EU_conv):

$$
p \_t \_m i l k=p \_t \_m i l k \_p r \_d g a g r i * p \_m i l k \_E U \_c o n v .
$$

Milk yield projection. A milk yield projection (milk_yield) was produced based on the milk yield increase trends based on historical data [19]. The changes in the milk yield also reflect the technological progress of the sector - use of better technologies, improved genetics, feeding and welfare impact the milk yield:

$$
\text { milk_yield }=f(\text { milk_yield }(-1)) .
$$

Costs. Purchased feed cost. Calculations of purchased feed costs (IZ_t_prch_feed) per tonne of milk produced employed the ratio of the total purchased feed cost (EUR) (PL_prch_feed_e) to the quantity of milk produced, tonnes, for the group of dairy farms ( $\left.P L \_m i l k \_t\right)$ (FADN data) [12]. It is considered that average farm tends to move toward to the practices of economically more sustainable farms. That includes milk consumption as a feed per calve:

$$
I Z \_t \_p r c h \_f e d=\left(P L \_p r c h \_f e d \_e / P L \_m i l k \_t\right) \text {. }
$$

The coefficient for the proportion of purchased feed cost (prch_feed_pt_coef) was calculated based on 2014 FADN data for the group of dairy farms, dividing the ratio of the quantities of purchased feed and milk produced, measured in tonnes, by the price of a tonne of wheat ( $\left.p_{-} t \_p w h e a t\right)$ :

$$
p r c h \_f e e d \_p t c o e f=\left(P L \_p r c h \_f e e d \_e / P L \_m i l k \_t\right) / p \_t \_p w e a t \text {. }
$$

Labour cost. Labour cost is calculated as the cost of labour per thou.t of milk produced. The labour cost is calculated by dividing the cost of labour for the group of dairy farms by the output of milk for this group, measured in tonnes [12].

A unit labour requirement $\left(l b \_h \_p t\right)$ is calculated by dividing the number of worked hours for the group of dairy farms $\left(P L \_l b\right)$ by the output of milk, tonnes, for this group $\left(P L \_m i l k \_t\right)$ and by multiplying by 1000 :

$$
l b \_h \_p t=P L \_l b / P L \_m i l k \_t * 1000 \text {. }
$$

The proportion of paid labour ( $p d \_l b \_p r o p$ ) is calculated by dividing the number of hours worked by paid labour $\left(P L \_p d l b\right)$ for the group of dairy farms by the total number of worked hours for this group $\left(P L \_l b\right)$ :

$$
p d \_l b \_p r o p=P L \_p d \_l b / P L \_l b \text {. }
$$

Paid labour input in hours per thou.t of milk produced ( $\left.p d \_l b \_p t\right)$ is calculated by multiplying labour input in hours per thou.t of milk produced $\left(l b \_h \_p t\right)$ by the proportion of paid labour ( $\left.p d \_l b \_p r p\right)$; in a similar way, a projection of paid labour input in hours per thou.t of milk produced is made - the above-mentioned projected indicators are multiplied. 


$$
p d \_l b \_p t=l b \_h \_p t * p d \_l b \_p r p .
$$

Unpaid labour input in hours per thou.t of milk produced (upd_lb_pt) and a forecast of unpaid labour input in hours per thou.t of milk produced are calculated by subtracting paid labour input in hours per thou.t of milk produced ( $\left.p d_{-} l b \_p t\right)$ from total labour input in hours per thou.t of milk produced $\left(l b \_h \_p t\right)$; in a similar way, a projection of unpaid labour input in hours per thou.t of milk produced is calculated - the above-mentioned projected indicators are multiplied.

$$
u p d \_l b \_p t=l b \_h \_p t-p d \_l b \_p t .
$$

Paid labour cost per tonne of milk produced $\left(I Z \_t \_p d \_l b\right)$ is calculated by multiplying paid labour input in hours per thou.t of milk produced $\left(p d \_l b \_p t\right)$ by unit labour cost $\left(P L \_l b \_u n i t \_c o s t\right)$ and dividing by 1000 ; a projection of this indicator is calculated similarly:

$$
I Z \_t \_p d \_l b=p d \_l b \_p t * P L \_l b \_u n i t \_c o s t / 1000 .
$$

Paid labour cost per tonne of milk produced and a projection of this indicator are acquired in the result of the above-mentioned calculations.

Value of and depreciation for investments in fixed assets. Two indicators relate to depreciation the value of an investment, which is the basis for calculating future depreciation for the investment of a farm and depreciation expense [12]. The value of investments per tonne of milk produced (IZ_invest_milk_t) is calculated by dividing the value of the investments in EUR for the group of dairy farms $\left(P L \_i n v e s t \_e\right)$ by the output of milk in tonnes for this group ( $\left.P L \_m i l k \_t\right)$. In a similar way, depreciation per tonne of milk produced $\left(I Z \_t \_d e p r\right)$ is calculated - the depreciation expense in EUR for the group of dairy farms (PL_deprec) is divided by the output of milk in tonnes for this group

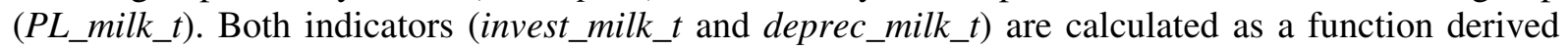
from the trend based on historical data (invest_milk_t and IZ_t_deprec):

$$
\begin{aligned}
& I Z \_i n v e s t \_m i l k \_t=P L \_i n v e s t \_e l P L \_m i l k \_t \text {, } \\
& \text { invest_milk_t }=f(\text { invest_milk_t } t(-1)) \text {, } \\
& I Z \_t \_ \text {deprec }=P L \_d e p r e c / P L \_m i l k \_t \text {, } \\
& \text { deprec_milk_t }=f\left(I Z \_t \_d e p r e c(-1)\right) \text {. }
\end{aligned}
$$

Total milk production cost. The total milk production cost was calculated using the FADN data [12]. Since the FADN data are general data on farms, often farm costs contain both milk productionrelated costs and costs that are not related to milk production but related to other kinds of economic activity. It is often impossible to divide costs by the kind of economic activity in the statistical database, as an employee, for example, is engaged both in the production of dairy products and in the production of other products as well. The situation with the exploitation of unspecialised machinery is similar. Not always farmers themselves can correctly classify production costs, as the production of various goods and services on their farms is an auxiliary economic activity.

For this reason, to calculate milk production cost per tonne of milk produced (IZ_t_milk) for the group of dairy farms $(P L)$, farm revenues from other economic activities have to be subtracted from the total production cost (PL_cost_t_e) (PL_rev_t_e - PL_rev_milk_e - PL_rev_beef_prod_e) (total revenue minus revenues from milk sales ( $\left.P L \_r e v \_m i l k \_e\right)$ and livestock production sales). Assuming that the farm revenue from other economic activities is equal to the expense in these activities, the cost is divided by the quantity of milk produced by the group of dairy farms ( $\left.P L \_m i l k \_t\right)$ in order to determine the cost per tonne of milk produced:

$$
I Z \_t \_m i l k=\left(P L \_c o s t s \_t \_e-\left(P L \_r e v \_t \_e-P L \_r e v \_m i l k \_e-P L \_r e v \_b e e f \_p r o d \_e\right)\right) / P L \_m i l k \_t \text {. }
$$

A projection of total milk production cost is calculated by multiplying the total milk production by a coefficient for the total milk production that consists of three components: purchased feed cost, labour cost and depreciation expense.

Number of dairy cows. A projection of the number of dairy cows (d_c_no_pr) $[19 ; 20]$ is made based on estimated milk output for the previous year (milk_tt_pr) and a projection of the milk yield (milk_yield_pr):

$$
d \_c \_n o \_p r=(\text { milk_tt_pr }(-1) * 1 e+06) / \text { milk_yield } \_p r .
$$


In view of the fact that in dairy farming cows are used for the production of both milk and meat, the projection of the number of suckling cows is considered as well.

Number of suckling cows. A projection of the number of suckling cows $\left(s \_c \_n o\right)$ is calculated based on the historical trend in the number of suckling cows (s_inc_pr) [20]:

$$
s_{-} \_\_n o=s \_c \_n o *\left(1+s \_i n c \_p r\right) \text {. }
$$

\section{Key results of the simulation of dairy farming}

In projecting the milk output, trends in the following three fields are taken into consideration: commercial production of milk sold for processing, own consumption of milk for food and own consumption of milk for feed. According to the projection, the highest milk output is going to be reached by 2030 (1241 thou.t). In the period 2016-2030, the output of milk is projected to increase steadily, while in the period after 2030 the milk output is projected to decrease to 1064 thou.t by 2050 (Fig. 1). Such results may be explained by a decrease in the number of dairy cows, which is expected for the period after 2025 (Fig. 3). The only dairy farm group that could increase milk production is the group producing milk for processing. Due to the increase in milk production, one can predict a greater need for new technologies and investment for the period until 2030. According to calculations based on the FADN data [12], overall revenues in dairy farming rise with the output of milk increasing and the milk price stabilising; the overall revenues correlate strongly $([r]>0.8)[21]$ with the value of investment, million EUR $(0.85$ at sig. $=0.002)$ and the fixed asset depreciation expense $(0.78$ at sig. $=0.007)$ and medium strongly $([r]$ is $>0.5$, but $<0.8)[21]$ with the value of gross investment, million EUR (0.51 at sig. $=0.128)$.

It is projected that the own consumption of milk for food and for feed is going to decrease until 2050, as the number of small farms is expected to decline, which, in its turn, reduces the own consumption of milk for food. The production intensification process in dairy farming, however, decreases the consumption of milk for feed; it is expected that in 2050 the own consumption of milk for feed will account for $5.5 \%$ of the total output of milk.

It is also projected that milk yields will steadily increase, reaching $8000 \mathrm{~kg}$ per cow in 2030 and $9190 \mathrm{~kg}$ per cow in 2050 (Fig. 2). This projection is affected by a number of factors: first, production intensification through shifting to more productive cow breeds and enhancing livestock selection and farming technologies, which currently contributes and in the future too will contribute to milk yield increases; second, the production intensification is also fostered by available EU funding for farm investment. The average milk yield in Latvia is affected by the size structure of herds as well. An analysis of the FADN data on milk yields for the group of dairy farms broken down by farm size shows that the differences among the farm size groups are significant - the milk yields are higher for large farms than for small ones, which is associated with the above-mentioned factors. Consequently, the average milk yield will rise with the number of small dairy farms decreasing and large farms prevailing in the dairy sector.

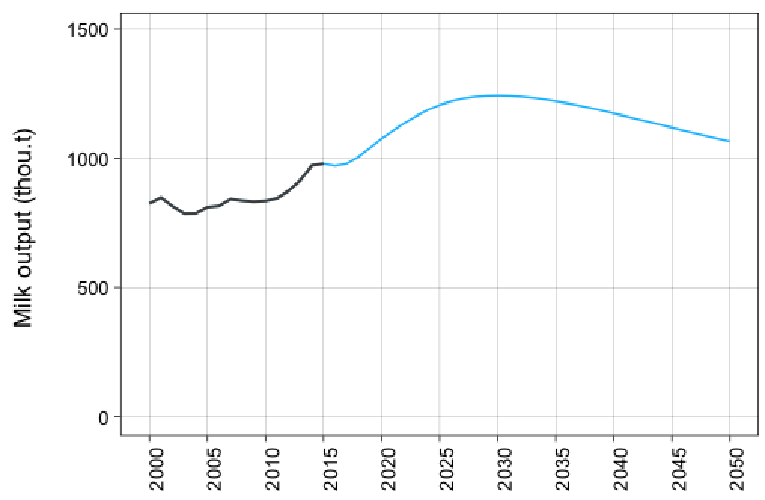

Fig. 1. Milk output in Latvia in 2000- 2015 and an output projection for 2016-2050, thou.t $[3 ; 9-17]$

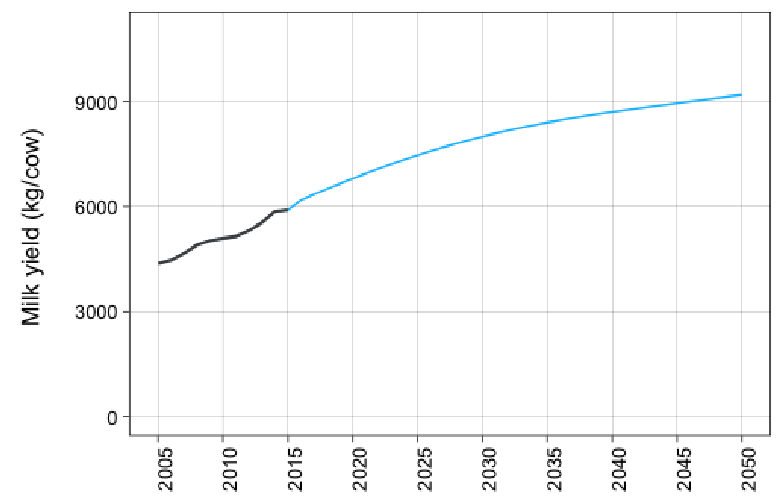

Fig. 2. Average milk yield in Latvia in 20052015 a projection of it for $2016-2050, \mathrm{~kg} \cdot \mathrm{cow}^{-1}$ per year $[9 ; 18]$ 
The number of dairy cows is expected to decrease (Fig. 3). By 2050, their number could reach 115 thou., compared with 185 thou. in 2015. However, no decrease is projected for the period until 2025 because the dairy sector is positively affected by EU support payments. Since the support payments are not going to increase after 2020, a decrease in profit margins in the dairy sector is possible over the next years, for some farm groups in particular, which will affect the total number of cows. The projection for the number of dairy cows was compared to a projection of another simulation model developed in 2015 [22] that had projected a much more optimistic increase in the number of dairy cows without a tendency to decline after 2025 as projected by LASAM. This can be explained by the differences of assumptions for each model - LASAM includes the influences of the support policies that consequently affect the profitability of a particular sector and change the tendencies for the increase or decrease of the number of animals in this sector.

Livestock farming for meat production is a relatively new sector in Latvia, which actually began emerging in 2003-2004 when meat cattle breeds were imported and the meat cattle started to be raised and selected in the country. A sharp increase in the number of suckling cows is expected in this sector in the period until 2025. After 2025, the projected number is constant at 77 thou. cows (Fig. 4).

It is difficult to project the development of livestock farming for meat production, as it depends on political factors (opportunities to export calves, support payments, emission policies). In Latvia, beef producers successfully cooperate and find markets for sales outside the country; therefore, this sector growth does not depend only on domestic demand. The opinions of industry experts on the sector development are diverse - a few of them believe that the sector has great opportunities for growth, while the others suppose the growth could stop in the nearest future.

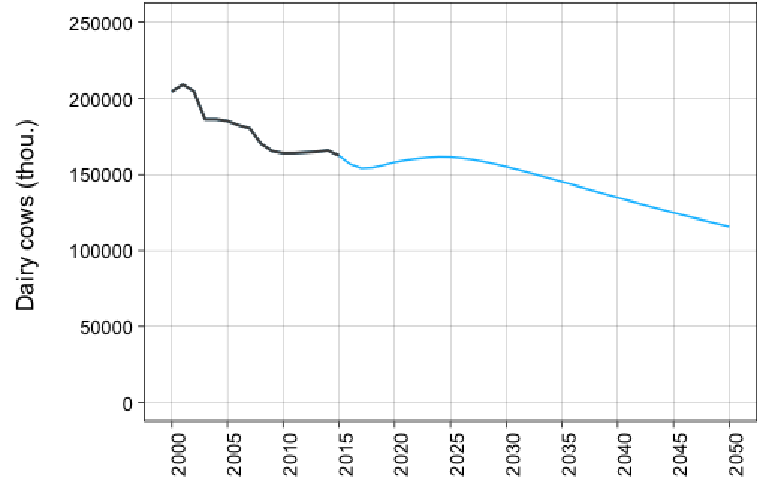

Fig. 3. Number of dairy cows in Latvia in 2000- 2015 and a projection of it for 2016$2050[9 ; 10 ; 18 ; 20]$

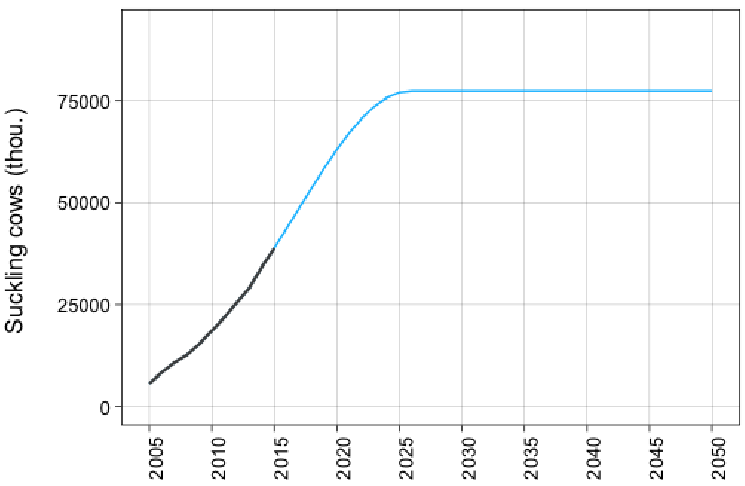

Fig. 4. Number of suckling cows in Latvia in 2005-2015 and a projection of it for 2016-2050 [9; 20]

According to a projection produced by the present research, an increase in area payments is going to stimulate the sector growth until 2020. However, after 2020 when the amount of area payments is going to stabilise, a gradual decrease in the sector growth is expected even regardless of the implementation of emission reduction measures. The sector growth could be promoted by government policies aimed at retaining a large area under permanent grasses without converting the area to grains and other crops. The eligibility criteria that limit the conversion of agricultural areas and are aimed at retaining the permanent grass area "unburdened" could stimulate relatively extensive livestock farming for meat production.

\section{Conclusions}

1. Agricultural modelling allows making projections for agriculture and its individual sectors for the purpose of applying different agricultural policy instruments. It provides fundamental input to policy developments in the EU.

2. Many factors were taken into account when simulating the dairy sector of Latvia: milk sold for processing, consumption of milk for food, consumption of milk for feed, milk prices, milk yields, the number of dairy cows, costs (total, as well as feed, labour and investment costs and depreciation expense). 
3. According to the projections produced by the model developed for dairy farming in Latvia: a) in the period 2016-2030 the output of milk is going to increase, while in the period after 2030 the milk output will slightly decrease owing to a decrease in the total number of cows; $b$ ) due to the increase in milk production, the need for new technologies and investment in the period until 2030 will be greater; c) milk yields will steadily increase until 2050; d) the number of dairy cows will decrease; e) the number of suckling cows will increase until 2025 and stabilize afterwards.

\section{Acknowledgements}

The research was promoted with the support of the project of the Ministry of Agriculture of the Republic of Latvia "Forecasting of Agricultural Development and the Designing of Scenarios for Policies until 2050", agreement No. 16-100-INV16-5-000001.

\section{References}

1. Latvijas lauksaimniecība 2016 (Agriculture of Latvia 2016). Riga: Ministry of Agriculture, 2016, 155 p. (In Latvian).

2. Nipers A., Pilvere I., Valdovska A., Proskina L. Assessment of Key Aspects of Technologies and Cow farming for Milk Production in Latvia. Proceedings of 15th International Scientific Conference "Engineering for Rural Development", May 25-27, 2016, Jelgava, Latvia, vol. 15, pp. 175-181.

3. EU Agricultural Outlook. Prospects for EU Agricultural Markets and Income 2015-2025. European Commission, 2015, 81 p.

4. Salputra G., Chantreuil F., Hanrahan K., Donnellan T., Van Leeuwen M. Policy Harmonized Approach for the EU Agricultural Sector Modelling. Agricultural and Food Science, vol.20, 2011, pp. 119-130.

5. Adenauer M. CAPRI versus AGLINK-COSIMO Two Partial Equilibrium Models - Two Baseline Approaches. 12th Congress of the European Association of Agricultural Economists, 2008, 4 p.

6. Borshchev A., Filippov A. From System Dynamics and Discreet Event to Practical Agent Based Modeling: Reasons, Techniques, Tools. The 22nd International Conference of the System Dynamics Society, July 25 - 29, 2004, Oxford, England, 23 p.

7. Kitchen N.R., Drummond S.T., Lund E.D. etc. Soil Electrical Conductivity and Topography Related to Yield for Three Contrasting Soil-Crop Systems. Agronomy Journal, vol. 95, 2003, pp. 483-495.

8. Jones J. W., Antle J. M., Basso B. O., Boote K. J., Conant R. T., Foster I., Godfray H. C. J., Herrero M., Howitt R. E., Janssen S., Keating B. A., Munoz-Carpena R., Porter C. H., Rosenzweig C., Wheeler T. R. Towards a New Generation of Agricultural System Models, Data, and Knowledge Products. State of Agricultural Systems Science, January 31, 2015, pp. 9-62.

9. Zinātniskā pētījuma Lauksaimniecības attīstības prognozēšana un politikas scenāriju izstrāde līdz 2050. gadam projekta atskaite (Report on the Project Forecasting of Agricultural Development and the Designing of Scenarios for Policies until 2050). Jelgava: Latvia University of Agriculture, December 2016, 98 p. (in Latvian).

10. RUG10. Piena produktu ražošana (Production of Dairy Products). Riga: Central Statistical Bureau. (In Latvian). [online] [12.09.2016]. Available at: http://data.csb.gov.lv/pxweb/lv/rupnbuvn/rupnbuvn_ikgad_rupn/RU0100.px/?rxid=cdcb978c22b0-416a-aacc-aa650d3e2ce0.

11. LLG024. Visu veidu saimniecību grupējums pēc liellopu skaita gada beigās (Grouping of Farms of All Kinds by the Number of Cattle at End of Year). Riga: Central Statistical Bureau. (In Latvian). [online] [14.09.2016]. Available at: http://data.csb.gov.lv/pxweb/lv/lauks/lauks_ikgad_05Lopk/LL0240.px/?rxid=cdcb978c-22b0416a-aacc-aa650d3e2ce0.

12. SUDAT datu bāze (FADN database). Unpublished resource. (In Latvian).

13. Milk Market Observatory. Historical EU Price Series of Cow's Raw Milk in Euro/100 kg and Historical Series of EU Average Prices of Dairy Products. [online] [12.09.2016]. Available at: https://ec.europa.eu/agriculture/market-observatory/milk_en. 
14. Atbalsta maksājumu datu bāze (Support payment database). Riga: Rural Support Service. Unpublished resource (In Latvian).

15. LLG008. Galveno lopkopības produktu ražošana (Output of Principal Livestock Products). Riga: Central Statistical Bureau. (In Latvian). [online] [20.09.2016]. Available at: http://data.csb.gov.lv/pxweb/lv/lauks/lauks_ikgad_05Lopk/LL0080.px/?rxid=cdcb978c-22b0416a-aacc-aa650d3e2ce0.

16. LIG0116. Piena iepirkums un iepirktā piena kvalitāte (Purchase of Milk and Milk Quality). Riga: Central Statistical Bureau. (In Latvian). [online] [18.09.2016]. Available at: http://data.csb.gov.lv/pxweb/lv/lauks/lauks_ikgad_01Lauks_visp/LI0116.px/?rxid=cdcb978c22b0-416a-aacc-aa650d3e2ce0.

17. LL053. Piena iepirkums, vidējā iepirkuma cena un iepirktā kvalitāte. (Milk Purchase, Average Purchase Price and Purchased Quality). Riga: Central Statistical Bureau. (In Latvian). [online] [18.09.2016]. Available at: http://data.csb.gov.lv/pxweb/lv/lauks/lauks__isterm_03Lopk/LL0530_euro.px/?rxid=cdcb978c22b0-416a-aacc-aa650d3e2ce0.

18. LLG012. Lauksaimniecības dzīvnieku produktivitāte (Livestock Productivity). Riga: Central Statistical Bureau. (In Latvian). [online] [22.09.2016]. Available at: http://data.csb.gov.lv/pxweb/lv/lauks/lauks_ikgad_05Lopk/LL0120.px/?rxid=cdcb978c-22b0416a-aacc-aa650d3e2ce0.

19. LLG022. Lauksaimniecības dz̄ivnieku skaits gada beigās (tūkstošos) (Number of Livestock and Poultry at the End of the Year (thsd heads)). Riga: Central Statistical Bureau. (In Latvian). [online] [22.09.2016]. Available at: http://data.csb.gov.lv/pxweb/lv/lauks/lauks_ikgad_05Lopk/LL0220.px/?rxid=cdcb978c-22b0416a-aacc-aa650d3e2ce0.

20. Lauksaimniecības datu centra publiskā datu bāze (Agricultural Data Centre public database). (In Latvian). [online] [16.09.2016]. Available at: http://pub.ldc.gov.lv/pub_stat.php?lang=lv.

21. Arhipova I., Balina S. Statistika ar Microsoft Excel ikvienam (Statistics with Microsoft Excel for Everyone). Riga: Datorzinību centrs, 2000, 136 p. (In Latvian).

22. Rivža P., Bērziņa L., Priekulis J., Lauva D., Mozga I., Valujeva K. Lauksaimniecības rādītāju un SEG emisiju no lauksaimniecības sektora prognoze 2020., 2030. un 2050. gadiem ar papildus pasākumiem emisiju samazināšanai (Agricultural Indicators and GHG Emissions in the Agricultural Sector Forecast 2020, 2030, and 2050 with Additional Measures to Reduce Emissions), Jelgava: Latvia University of Agriculture, 2015, 78 p. (In Latvian). 